\title{
A Study on Chinese Export Porcelain's Religious Culture in Ming and Qing Dynasty
}

\author{
Chen Wanting, Zou Guohao \\ School of Design and Art Department, Jingdezhen Ceramic University, Jingdezhen, China \\ Email address: \\ 2010012012@stu.jci.edu.cn (Chen Wanting), 913247461@qq.com (Zou Guohao)
}

To cite this article:

Chen Wanting, Zou Guohao. A Study on Chinese Export Porcelain's Religious Culture in Ming and Qing Dynasty. International Journal of Literature and Arts. Vol. 9, No. 5, 2021, pp. 242-250. doi: 10.11648/j.ijla.20210905.15

Received: September 18, 2021; Accepted: October 12, 2021; Published: October 19, 2021

\begin{abstract}
Chinese export porcelain was a great wonder in the long history of the world. During Ming and Qing dynasty, it was exported in large quantity beyond China, which led to a taste for Chinese designs and made different cultures encountered, exchanged and integrated. At the same time, Chinese export porcelain actively influenced passively recipient foreign consumers, which made the world civilization be promoted. The utensils are used to convey Daoism. While spreading Chinese culture, Chinese export porcelain carried the world's religious culture such as Christian culture, Islamic culture, Buddhist culture and Chinese local Taoist culture, bursting with colorful light. By collecting a large number of images of the Chinese export porcelain in religious culture during Ming and Qing dynasty, this article uses historical research method and the method of anthropology to make a specific and comprehensive analysis of the religious culture on exported porcelain so as to reappear the splendid global history. This article also elaborated on the design semantics, acceptance, and innovative development of religious culture on exported porcelains during the Ming and Qing Dynasties under the environment of the source language and target languages in China and beyond China. This article also analyzes the transportation routes and specific loading methods of porcelains during the Ming and Qing Dynasties, which better reflects the movement of Chinese Ceramics and its appropriation in world history. The methods of iconology are used in this article and the narrative stories on porcelains are analyzed. Chinese exported porcelain is functional and its spiritual enlightenment is appreciated by human-beings. The world civilization, human-being's wisdom, spiritual connotation, communication integration and mutual development of all the world's nations are witnessed by Chinese export porcelains in Ming and Qing Dynasties.
\end{abstract}

Keywords: Chinese Export Porcelain, Religious Culture, World Civilization, Cultural Communication

\section{Introduction}

Chinese ceramics have a special artistic charm. For over a thousand years, Chinese porcelain was the most universally admired and most widely imitated product in the world. [1] The ancient Chinese document Yin Liu Zhai Shuo Ci says that "sincerely, the beauty of Chinese porcelain is famous all over the world. Although it is imitated by hundreds of countries, Chinese porcelain is impossible to achieve, maybe it is a gift from God. [2] During the Ming and Qing Dynasties, a large number of custom made ceramics from the Middle East and Europe appeared, which were called "export porcelains." Archaeological excavations have proved that the export of Chinese porcelain began in the Tang Dynasty at the latest, and are usually exported abroad as a special product. After the Song Dynasty, with the increasing number of ceramic products exported, the Maritime Silk Road also became the "Ceramic Road" at the same time. A considerable part of these export porcelains are fired in accordance with the order contract and according to the needs of the overseas market. During the Ming and Qing dynasties, the decorative patterns of many export porcelains were based on samples brought by foreign merchants from overseas and then Chinese ceramic workers imitated the custom-made pattern on porcelains and fired them in the local kiln. Therefore, many export porcelain patterns had Islamic or Christian decorative elements. Among these export porcelains, a small part of them are marketed in Japan, India and other export porcelains with Buddhist decorative elements, and some export porcelains without special custom standards have Chinese local artistic styles, that is, Taoist cultural elements. So it can be inferred from above that Chinese porcelains which were exported to 
Europe normally had two kinds: one type was the Chinese local porcelains being exported outside, which expressed Chinese traditional cultures, religions and art; another one type was the custom made porcelains which were made according to the patterns and samples brought by someone from abroad. [3] It influenced virtually all ceramic traditions it encountered, and in some cases - most notably in maritime Southeast Asia and coastal East Africa or even Europe-it displaced them altogether, reaching deeply into religious and social life. The export routes of Chinese porcelain are mainly divided into land route and sea route. The land route is the Silk Road, which starts from Xi'an, passes through Gansu Corridor, the Tianshan Mountains in Xin Jiang Province, the Black Sea in the Central Asia, and reaches the Mediterranean coast, then to Europe. The sea route is called the sea ceramic road, mainly from Guangzhou, Mingzhou and other ports to Japan, North Korea, south to Southeast Asia, and to Africa via the Indian Ocean. Chinese export porcelain has three attributes: practicality, commerciality, and artistry. Practicability makes porcelain closely related to all aspects of life, closely related to the living habits and customs of different regions, so it reflects the regional, local and national characteristics to the greatest extent. The nature of business makes porcelain be restricted by market demand in the process of exchange. In other words, its design and production must meet the needs of market consumers, so it must accept the special requirements of foreign cultures. [4] The design and decoration of Chinese export porcelain surpassed its practicality and commerciality, and became a carrier of spiritual values such as aesthetics and belief expression. As a cultural focus, Chinese export porcelain can visualize the spiritual beliefs, customs, and even ways of thinking that comes from different nationalities, countries, and cultural backgrounds. Chinese export porcelain clearly expresses and reveals the spiritual religious beliefs and cultural psychology of people from different countries in the East and the West with its concrete shapes, patterns and painting art, resulting in a world-wide cultural blending phenomenon. The power of design and culture makes Chinese porcelain a medium for spreading cultural ideas and national spirit. With its unique and concrete shapes, patterns and paintings, Chinese export porcelain conveys the religious beliefs and ideas of people from different countries, and has become a media for religious culture. Its practicability, commerciality, and artistry allow it to participate in the global cultural cycle. Chinese export porcelain is not only the messenger of Western religious thought, but also the "westward" messenger of Chinese religion and folk beliefs.

\section{The Light of Christ on Chinese Exported Porcelain}

In a common sense, Jesus porcelain is the porcelain with Christ elements. These utensils are mainly custom-made by the West, including holy water vessels used in churches, statues of the Virgin, etc. In the middle of the $16^{\text {th }}$ century,
European missionaries ordered religious porcelain from Jingdezhen folk kilns, which were mainly painted on groups of tea sets for religious occasions. [5] Porcelains related to Christ elements are usually called Jesus porcelains. Starting in the $17^{\text {th }}$ century, decorated porcelains with Christian themes such as Bible stories and cross elements were appeared in China. The porcelain is painted with religious story patterns such as the stories in the Bible depicting the characters such as Jesus, the Virgin, and angels. The rim, neck, and feet of the porcelains are decorated with Chinese patterns such as curly flowers and leaves, as well as the Ruyi patterns, forming the "Jesus Porcelain" with Christian characteristics during the Ming and Qing Dynasties. [6] Jesus porcelain became popular in Ming Dynasty and reached its peak in the Qing Dynasty. From the research on Jesus porcelain, we can have a glimpse of the development track of China's export porcelain, hence, the course of cultural exchanges between China and the West is better witnessed.

In addition to the skill of underglazed blue and white decoration, decorative techniques such as ink color drawing on gold, blue and white glaze with red spot and famille decorative skills are used on Jesus porcelain. The ink color porcelain is mainly painted with black color as well as staff red and gold, and the painting is naturally dried and then fired in a kiln. According to the letter of the French missionary Père Francois Xavier d'Entrecolles to the Pope, it was only after 1722 that Jingdezhen successfully fired ink-colored porcelain. The Christian-element export porcelain saucer was sold to the Dutch market during the Qianlong period of the Qing Dynasty (Figure 1), kept by the resident Chinese diplomat Andrew Franklin (Andrew Franklin). It was made in 1740 and permanently collected by the Birmingham Museum (Birmingham Museum). The saucer is painted in pastels, and the middle of the saucer is a typical Christian element. Jesus was nailed to the cross. Influenced by the gravity of the earth and human body, the crucified body of Jesus drooped naturally. On both sides of the cross are the Virgin Mary, the mother of Jesus, and the apostle John the Baptist. It can be judged from the picture that the ceramic saucer is made of pastel craftsmanship. The glass-white background can be clearly seen on the Jesus waist apron and the purple shawl of the Virgin Mary. The complementary colors of beige and purple make the color softer. The pastel saucer presents a triangle from the picture composition, which gives people a sense of stability visually and is in line with the stable function as for the saucer. It should be noted that this saucer is custom-made from the West, because the painting was used perspective techniques. Chinese painters tried their best to imitate the western perspective techniques, but the face they painted was not that good. They haven't sketch the facial contours. However, it reflects more of the plane face, which was influenced by traditional Chinese ink painting skills.

It must be emphasized that Jesus porcelain with Christ elements as its narrative theme is not limited to one object when it uses patterns to express the story of the picture. Instead, it connects several objects in series to make the story easier to be understood. Porcelain plate with ink and color 
inscription on the "Crucifixion of Jesus"(Figure 2) and "Resurrection of Jesus"(Figure 3) are from the collection of the Guangdong Museum during the Qianlong period of the Qing Dynasty. The creation of the whole set of porcelain $\mathrm{s}$ comes from the "Bible" Matthew 20:18-19: "Behold, when we go to Jerusalem, the Son of Man will be handed over to the chief priests and scribes; they will condemn him to death and give him to outsiders. The people teased, whipped, and nailed to the cross; on the third day he will be raised. This set of ink-colored Jesus porcelains (Figure 2 and Figure 3) are the complete presentation of the Bible story in different vessels, which are easy to be understood.

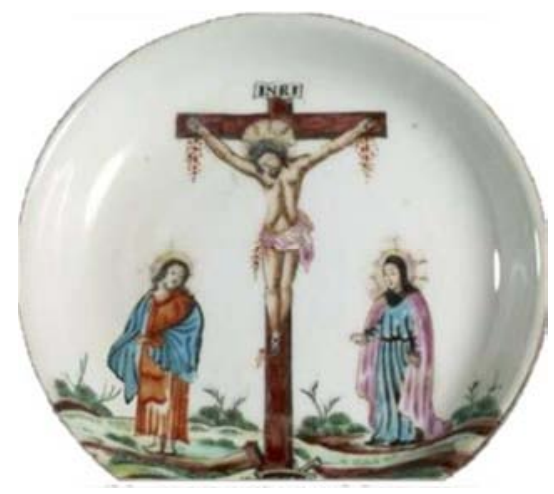

Figure 1. Chinese Export saucer.

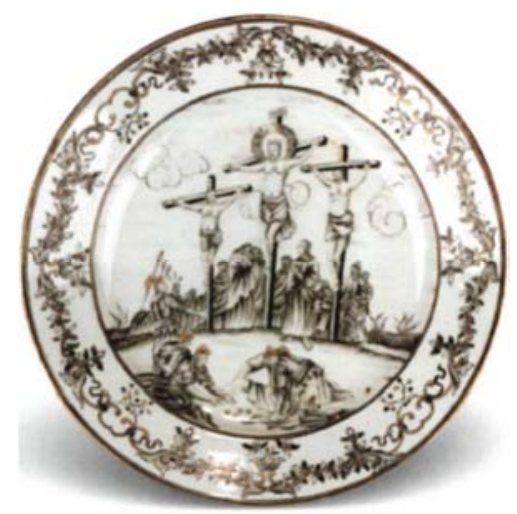

Figure 2. Ink painting porcelain of Crufixion of Jesus in Qing Dynasty.

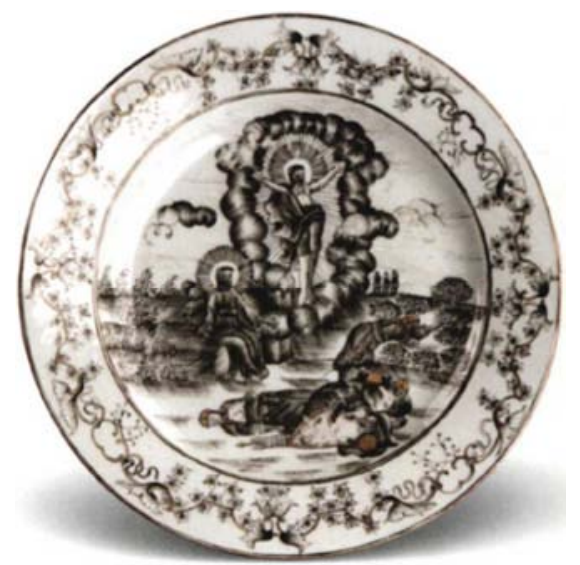

Figure 3. Ink painting porcelain of Jesus Resurrection in Qing Dynasty.

This set of pictures porcelain plates are of the same size to create continuous narrative stories. The porcelain plate puts the story description in the center of the picture, and the periphery of the picture is surrounded by a circle with a plant ring, which further highlights the picture of "Jesus Passion" and "Jesus Resurrection". From figure 2 we can see that Jesus was hanging on the cross in the center of the picture, and the auspicious cloud patterns above the cross which depicts the classic picture of "The Crucifixion of Jesus", showing the glory and sacredness of victory over $\sin$ and death on the cross. Figure 3 is the scene of the resurrection of Jesus. The thick smoke billowing next to Jesus even more clearly shows the glory and victory of the mighty God of Jesus as the King of Kings and Lord of Lords. The whole picture adopts dark and gray tones, adapting to the solemnity of the religious culture of the crucifixion and the resurrection of Jesus.

Another type of artifacts are the ones with typical Christ patterns or symbolic elements of this type, such as crosses, doves, vines, and symbolic elements mentioned in the Bible. The pictorial images are generally centered on crosses or doves, Jesus figures, etc and are complemented by the smart and graceful Chinese curly grass patterns. The following pictures (Figure 4 and 5) are custom-made classic patterns for export porcelain. (Figure 4) The production time is between 1690-1700. The cross of Christ is on both sides, surrounded by tulips on both sides, and inlaid with a hard metal base at the bottom. Both sides are embossed with lion heads. The height is $19.5 \mathrm{~cm}$, and the picture is from Christie's Auction in London. Figure 5 is a blue-and-white jar sold in the UK market. It has a cross on both sides, separated by a tangled pattern that grows from the bottom of the cross. It was produced in $1690-1700$ and is $81^{1 / 16}$ inches high. The patterns of the two porcelain jars are of the same design, the only difference is that the mouth of the porcelain jar (figure 5) has a ring with tangled branches. From the time point of view, the production time of the two porcelain jars is similar. It can be seen that this pattern is all the rage in the European market. From the perspective of decorative details, the two similar jars are made by different painters and fired in different kilns. The porcelain body of Figure 4 is pure and white, the small dots at the curled leaf pattern are plump, the lines around the branches are strong, the blue and white water is light and even and the blue and white tones are bright, which can be described as a good product. The mouth and sides of the porcelain jar base are inlaid with metal, which is beautiful and elegant. It enhances the stability of the porcelain placement and also provides better protection for the porcelain jar. The hanging rings on both sides make it convenient for people to lift it by hand and the design is reasonable in line with ergonomics, giving people a beautiful enjoyment. The bottom of the porcelain jar (Figure 5) is in greyish-blue, which shows that the reducing atmosphere of the firing kiln is strong, and the iron element in the porcelain body is not completely burned. From the decorative details, the porcelain in figure 5 is also slightly inferior. The flower stems and leaves are drawn flat and in subsidence, stems and leaves are weak. Blue and white water separation is unclear, and some of the colour appears black. Based on this analysis, it can be inferred that the porcelain jar showing in figure 5 may be a device for mass production of 
civilian kilns. It should be noted that there is a similar trace in the painting techniques of the two porcelain jars and it is the skill of the painting of Jesus Christ on the cross. At that time, porcelain craftsman might not understand the perspective principle of Western painting, and the proportion of the human body painting was out of balance. During these reasons, the facial features were not obvious. Both arms on the cross are perpendicular to the vertical wooden poles, which does not reflect the state of the body sagging under the influence of gravity. Therefore, faced of unfamiliar custom samples and unfamiliar Western stories, Chinese potters' painting techniques fully reflects their romantic imagination to the west.

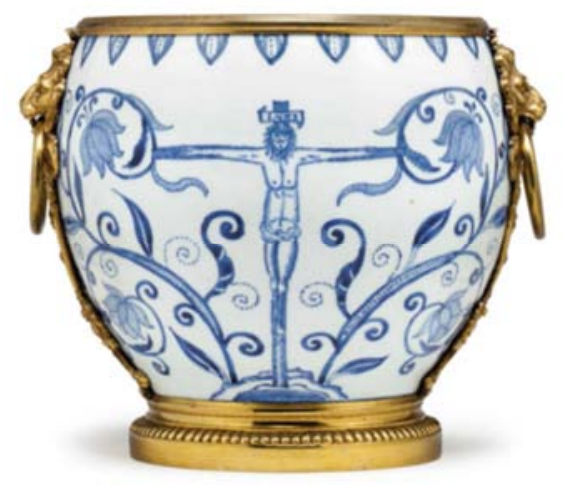

Figure 4. Chinese export jar with blue and white cross decration.

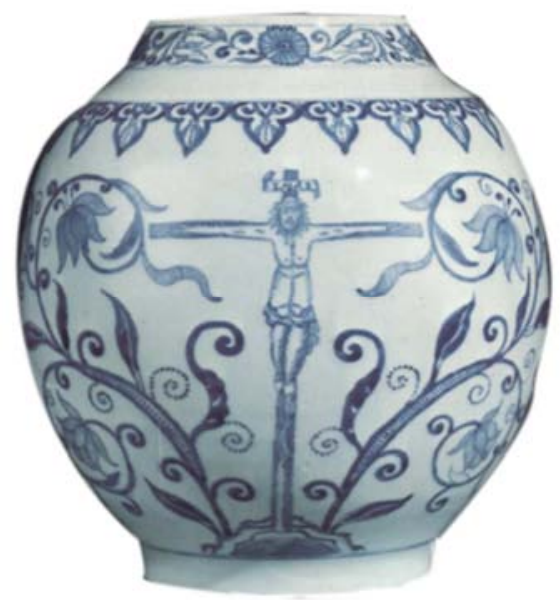

Figure 5. Chinese export jar with blue and white cross decoration.

\section{The Islamic Light of Chinese Export Porcelain}

The ceramics are the bulk commodities of overseas trade being sold overseas in large quantities through the sea ceramic road to meet the economic, political, cultural, religious and other life needs of local people. The loading of the sea porcelain trade has its unique features, reflecting the superb design wisdom of the ancients. Figure 6 is the shipping loading map of export porcelain by sea, gouache, created in the early $19^{\text {th }}$ century, $15 \times 19^{1 / 8}$ inches. These porcelains are packed in wooden packaging made of bamboo chips. The gap between the plate and the plate is filled with sago to prevent the export porcelain plate from shaking or colliding. It should be noted that these sago are also exported to Western countries in China's export trade. The number of bamboo boxes loaded on each ship is different. Take the Princess George in 1755 as an example; it loaded 120 wooden boxes with about 74,000 porcelain [7]. Sago fills the gap between the plate and the plate with its characteristics of flowing and filling the solid space, reducing the collision between the plate and the hard objects of the plate, and the sago has its low-density physical properties. Between the plates and the bamboo planks, it seems like modern plastic foam making transportation safer and more convenient. The porcelain is carried on the ceramic road on the sea. With the force of the sea, the gap between the sago and the porcelain is getting smaller and smaller, and the three objects are completely Integrated into one. This kind of loading method has multiple functions such as saving carrying space, preventing porcelain from breaking and being easier to transport.

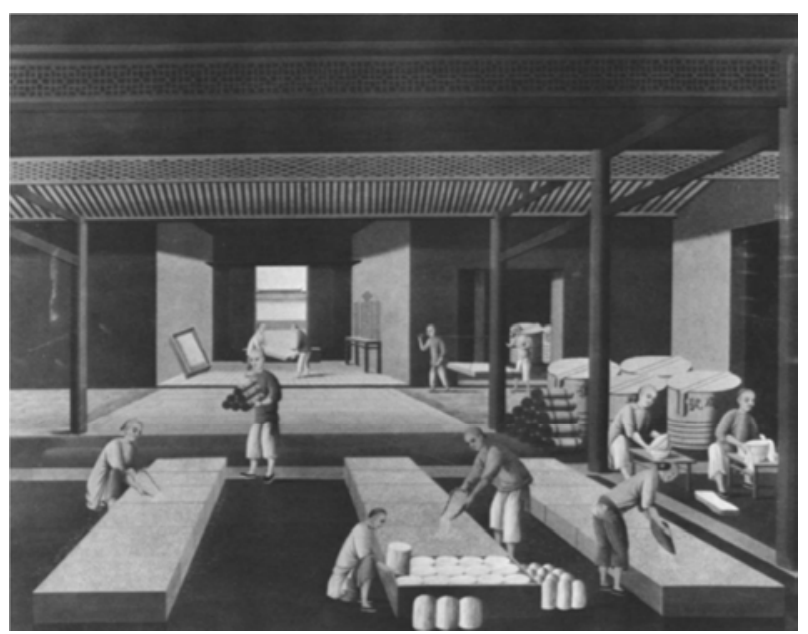

Figure 6. The stowage picture of Chinese export porcelain through sea road.

This chapter takes Guangzhou colourful painting porcelain sold to Iran, Egypt and other places in the Arab region as an case to deeply analyze the spiritual civilization of the Islamic world carried on the artifacts. Most of them are sold in today's Iran, Egypt and other places. These Guangzhou colourful painting porcelains are mainly large bowls and plates, and the decorations of the utensils are basically in the style of red, green, and gold. Patterns and ornamentation rarely have storytelling. The descriptions of saints and characters are mostly flowers, birds, grass, trees and geometric decorations.

"Islamic Art" from Jonathan Bloom has the following description of Islamic art said below that" The Islamic decorations in the domes of most churches contain some fantastic trees, plants, fruits, jewelry, communion cups and crowns; It is not like the Byzantine architecture. It has stories from the Old Testament and New Testament of the Bible, or shows heartfelt pictorial scenes for Christ, the Virgin, and the saints. The religious art does not draw figures or animals. The 
lack of character images is a typical feature of Islamic religious art. It is said that character painting was banned by Islam from the beginning, but it is not true. The Quran rarely mentions this topic. Muslims believe that God is unique and irreplaceable, and there is no intermediate linker. The believers can directly worship the gods, so the image of saints is not allowed to appear. The Quran has few narratives in this regard, and the story patterns of these characters never appear in religious art, and this is also included in the "Islamic law". [8]

The artistic decoration of Islamic ceramics is mainly decorated with curly grass patterns, plant patterns, and geometric patterns. The classic texts in the "Quran" are added as decorations to enhance the spiritual civilization of the utensils. Based on the Islamic ceramics that the paper has found, messages can be inferred that ceramics fired in China can be divided into two types: official and civilian use. The official use is less and the civilian use is more. For official use, there were strict regulations on patterns and text usage, which were generally customized by the church at that time, while the civilian use was not so strict. The pattern decoration is mainly curly plant patterns, butterfly patterns, and Islamic characters. Butterflies are the most beautiful insects in the insect kingdom. They are hailed as "flying flowers" and "beauties in the insect kingdom". Since ancient times, it has been loved by people for its beauty. "Blessings of Love" is a well-known love story among folks, and the beautiful melody of "Huadie" has moved people deeply for a long time. The butterfly is a representative of elegance and beauty, and a symbol of happy love. The butterfly pattern of celadon in Yue kiln has appeared in the late Tang Dynasty. [9] The butterfly, as a kind of auspicious ornamentation, reached its peak in the Ming and Qing dynasties. [10] The butterfly pattern on the porcelain (figure 7) may be influenced by Chinese traditional culture as well as the Auspicious pattern. The homonym of butterfly is "good fortune overwhelming". This trade was to change the material culture of Arabic, bringing with its new objects, colours and patterns.

A large bowl of Arabic figures from the Daoguang period in the Guangdong Museum (Figure 7) ${ }^{1}$ was made in 1846 (the twenty-sixth year of Daoguang). The center of the bowl was decorated in Arabic. According to the interpretation, this Persian text is the content of the bowl's set-boiler Haoji Hasm praying to Imam (leader) Hussein: "Bright, holy, brave and fearless Imam Hussein. I will take the name of Imam Hussein both in this life and in the hereafter, and I am willing to be the slave of Imam Hussein. As my guider, he will help me cleanse my dirt in the world and take me to heaven. Mahmu Hussein inherits the mantle of the Prophet Muhammad, spreads the teachings of the Quran, fights the enemy bravely for the sect. He sacrificed for the religion in Karbala and all the Muslims mourn for his death. I will go to the mosque to pray every day. May Imam Hussein bless my family, guide us the way forward, and bring us light. The humble Haji Hassm in 1846." [11]

1 This figure comes from the book Huang Jing, 2017. Cantonese Porcelain Sold to the Arab Region, India and Latin America. Xi An: Collection. p 103.
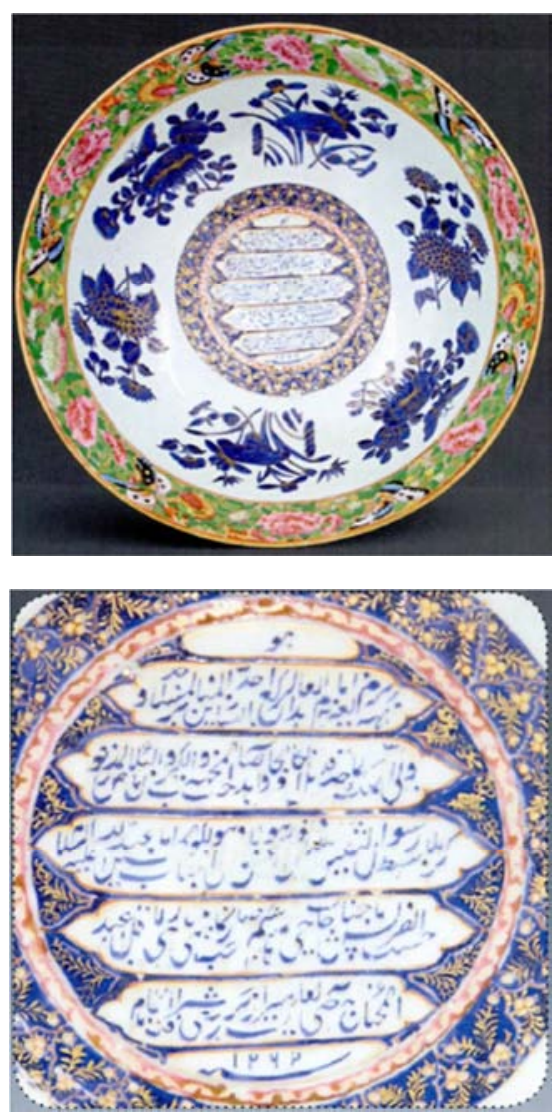

Figure 7. The Cantonese porcelain bowl with Arabic characters.

From the Arabic characters decorated on the center, we can see that most of these utensils are custom-made by Muslims, using porcelain as a carrier and the brilliant words from Quran are wrote on the porcelain with blue and white cobalt materials. Without a doubt, these daily utensils meet the needs of life. During the time of the feast, there is not only the aesthetic view of the decorative patterns, but the spiritual needs are met. The outermost ring of the porcelain plate is decorated with a ring belt. The saying "Thousands of flowers do not fall to the ground ${ }^{2}$ [12], and a little red in great green" adapts to the culture of the Islamic region. The central ring is decorated with blue and white local plants. In the center of the porcelain plate, prayer texts are written in Islamic characters, embellished with golden water and fired out like gold, highlighting the expensiveness of the porcelain plate and the saint's dedication to the pursuit of faith.

\section{The Light of Buddhism on Chinese Export Porcelain}

After Buddhism was introduced to China, the production of Chinese ceramics gradually incorporated with Buddhist elements, and was influenced by Buddhism in form and decoration. The Buddhism culture on export porcelain is

\footnotetext{
2 "Thousands of flowers do not fall to the ground" is a composition method which is popular in Ming Dynasty, China. It is also called the method of "brocade everywhere".
} 
mainly embodied in two aspects: modeling and decoration. The modeling includes the shape of the utensil itself and the porcelain sculpture. The decoration is mainly reflected in some decorative paintings. After Buddhism culture was introduced into China, due to its obvious localization in China, Taoist culture became folk beliefs in China. Ceramic works carrying Buddhist culture are sold in limited areas, such as Japan, India, and Tibet. The models mainly include monk pots, holding pots, figure porcelain figurines, Buddhist auspicious animal figurines. As for the decoration, the element symbols mainly include the lotus pattern and the honeysuckle pattern; From the perspective of the Buddha portrait system, the common ones include Bodhisattva statues, Tianlong Babu statues, Arhat statues, Buddha biography pictures, Jataka pictures, story pictures, mountain temple pictures, miscellaneous pictures and so on.

Here in Figure 8 is a pair of Incense Burner in Shape of Lion which belongs to Jingdezhen Celadon and White Porcelain in Yuan Dynasty collected by the Metropolitan Museum of the United States. The height is $22.2 \mathrm{~cm}$, and it was produced and customized in 1400. The porcelain lions are looking at each other which makes them more vividly. Lion is not an animal native of China. However, due to the close relationship between the image of the lion and Buddhism, the image of the lion gradually became popular after Buddhism spreading to China. In the "Buddha Amitabha Sutra", there are six representative Buddhas in the world below, among which the first sacred name is Master Buddha (Shi Tong Lion); In addition, the mount of Manjushri is a blue lion, and the lion is also the protector of Manjushri; Another example is the Buddhist classic "Ksitigarbha Sutra", which also has a description that "Lion Fenxun has the full power of ten thousand actions"; In Buddhism, it is also called the lion roar [13]. The sound of the lion roar can inspire the deaf and correct the prejudices.

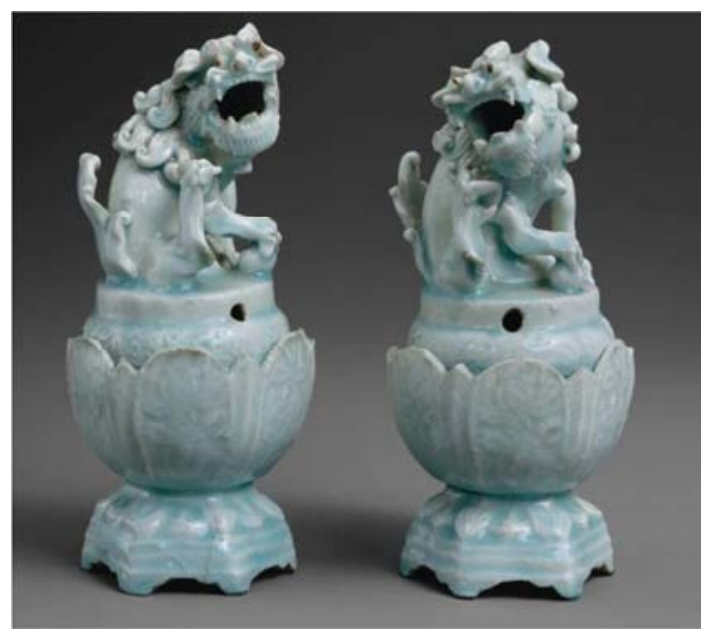

Figure 8. Incense Burner in Shape of Lion.

In addition, the lion is the king of the beasts. It has the characteristics of dignity, majesty, and strongness. In traditional Chinese culture, the lion has gradually evolved into a symbol of majestic and sole proprietorship as well as an animal image with a symbol of exorcising evil and avoiding evil. Under such a cultural background, the male and female images of the lion have gradually been fixed. In Buddhist culture, lions are generally guardian animals of Guanyin and are regarded as an auspicious image. The lotus pedestal is also an auspicious meaning in Buddhist culture. [14] The combination of the lion and the lotus pedestal embodies the enlightenment of the Buddhist culture. The unique blue and white plain glaze decorated in Jingdezhen also embodies the pursuit of beauty in the Buddhist culture, which means purity in spirit. Craft culture, like other cultures, has no national boundaries. In Buddhist culture, the lion is a symbol of auspiciousness and protection. However, in Islamic culture, the lion generally symbolizes courage and perseverance. Therefore, this pair of Jingdezhen blue-white porcelain lion censers with lotus base was purchased by Buddhists outside the territory, but it may also be appreciated by Muslims.

What needs to be explained is that, as a cultural symbol, the cultural meaning of ceramic art may be changed when in the source language and target language. Guanyin porcelain sculptures are more understandable in China as Buddhist culture. It is a goddess in China that help every household prosper generations, have mercy to the poor and fight the evil, while in the Western world, its holy and beautiful image is more reminiscent of the Virgin Mary. In China, Guanyin is in the hearts of people as a symbol of happiness with a kind face, graceful posture, joy and peace. Western missionaries or businessmen who came to China were also deeply attracted by the image of Guanyin. The white glazed porcelain sculpture was spotless with shape elegant, skirt in soft Rococo curve design, stepping on the lotus flower and riding the raging waves. Wherever he goes, there is goodness and grace, which is similar to the image of the Virgin Mary in Western Christianity. Therefore, Guanyin porcelain sculptures are greatly favored by the West as an export product. This visual symbol represents different cultures in the source language and target language. It also reflects the exchange and mutual learning of Chinese and foreign cultures;

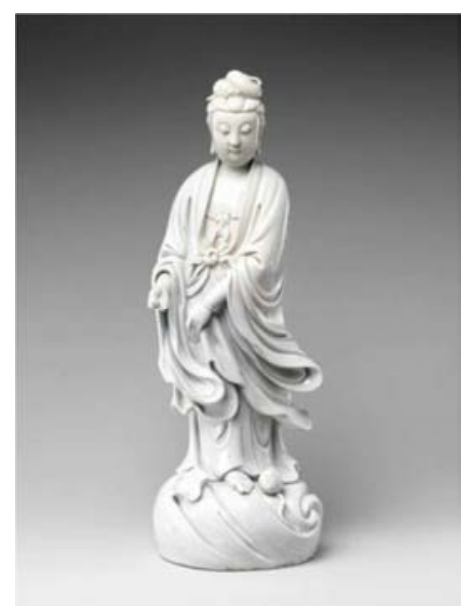

Figure 9. Bodhisattva Guanyin.

The White Porcelain Guanyin Statue of Dehua Kiln in the Late Ming and Early Qing Dynasty (Figure 9), $41.3 \mathrm{~cm}$ high, is 
now in the Metropolitan Museum of America. Chinese Buddhism was introduced into China from India, and gradually developed its own characteristics after localization. The statue of Guanyin is asexual or male in India, but it is more common as a female image in China. Its triple attributes, such as practicality, commerciality, and artistry, have played a unique and important role in the world's "cultural cycle". Japanese scholar Kyosuke Ueda said in the paper Introduction to the Research on Ancient Chinese Ceramics: "From about the $16^{\text {th }}$ century, after Dehua white porcelain was introduced to Europe, it was immediately appreciated and welcomed by the aristocracy throughout Europe as Chinese white porcelain. And Dehua white porcelains were in unlimited orders." The white porcelain Guanyin statue is popular among Japanese Christian believers as the icon of Mary, and the demand for it is almost astonishing." [15] It can be seen that when ceramic decorations and modeling symbols break away from the local language and enter a foreign environment, they will have different interpretations for readers from different cultures. This is also an interesting part of design and culture. Different cultures, customs and beliefs are crossed and explained by Chinese export porcelain, which exude a unique fragrance in the long history of the world.

\section{The Taoist Light on Chinese Exported Porcelain}

Christianity, Islam and Buddhism are the world's three major religions. In addition to the three major religions in the world, Chinese export porcelain has Taoist cultural elements in its shape and decoration due to the influence of local culture. The Taoist culture on Chinese export porcelain interprets the fairy beliefs, natural inaction, and longevity in ancient Chinese culture, which are derived from the Taoist cosmology of traditional philosophical thinking. Nearly a hundred pieces of porcelain in the collection of Frederick Augustus II are representative of Taoist themes, and their themes are concentrated on advocating "the way of immortality is valuable for life" and the doctrine of "valuing people and life". [16]

The porcelain Multicoloured porcelain with Daoism painting in Figure $10^{3}$ is $39 \mathrm{~cm}$ in diameter and $6.4 \mathrm{~cm}$ high. In the center of the dish there is a circle painted on it and inside there is a Taoist inner scripture picture. The lower part of the picture depicts Taoist temple, the middle part is painted with a plume of blue smoke and towers with colour, and the upper part is painted with Taoist buildings such as Jiufeng Mountain, Jufeng Mount and Nimaru Palace. The "Multicoloured porcelain with Daoism painting porcelain" is a typical Zhangzhou Taoist theme in the Ming Dynasty. The image conveys the potter's understanding of life at that time. The design of Taoist Wonderland tells us directly and clearly that this is a group of people who desire to live in a fairyland

3 This figure comes from the article Huang Zhongjie. Art Studies about Collections of Chinese export Porcelains of Augustus II, King of Poland, Fujian Normal University, doctoral degree paper, 2012. p65. where they do not eat grains, breathe in the wind, drink dew, ride on the clouds, and fly like dragons ${ }^{4}$. They pursue the concept of emphasizing human-beings and life, praying for immortality and becoming immortal. People regard the body as the foundation of everything. From the sensation that our body touches the outside world, we realize the unity of nature and human-being. The core view of Taoism in the late Ming Dynasty contained profound cultural connotations.

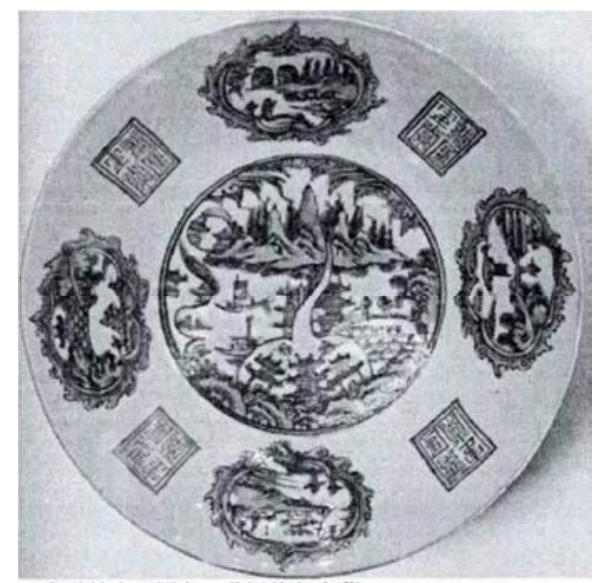

Figure 10. Multicoloured porcelain with Daoism painting.

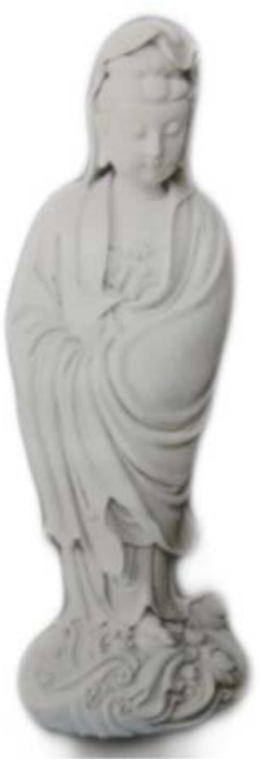

Figure 11. Dehua porcelain with ivory glaze Guanyin.

Apart from the plane painting on the ceramics, the Taoist element of porcelain is also displayed in the three-dimensional shape of ceramics. The most famous of all is the white porcelain statue of Fujian Dehua, Dehua

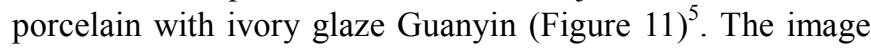
of Guanyin is dignified and solemn, gentle and elegant, and approachable. Dehua white porcelain is deeply loved by the West because of its white appearance and holy nature. The

4 Here dragon represents an auspicious animal in China;

5 The figure comes from the book Editor in chief by Geng Baochang, Tu Hua, Ye Wencheng, etc.: "A Series of Famous Ancient Kilns in China-Dehua Kiln", Nanchang: Jiangxi Fine Arts Press, 2016, p.132. 
appearance is as white as jade, and the demeanor is kind and peaceful. It reflects Taoism culture in China, but it is regarded as a symbol of sacred and nobleness in the West, and it is honored as the image of the Virgin. However, East and West's preference for white colour and other elegant colors encountered here coincidentally. Li Yu's "Xian Qing Ou Ji" in the Qing Dynasty records:" The color of red, purple, deep and gorgeous is not of fashion and seems no better than light colour. This is what we said that elegant is better than expensive." [17] The East has a preference for light colors, reflecting the elegance of the officials and scholars, while the West regards neutral white as sacred. The Japanese scholar Kyosuke Ueda said in the book Introduction to the Research on Ancient Chinese Ceramics: "From about $16^{\text {th }}$ century, after Dehua white porcelain was introduced to Europe, it was immediately appreciated and welcomed by the aristocracy throughout Europe. As the design and style of luxury, a civilised way of life [18], Chinese Dehua white porcelain was in great and unlimited ordering". "The white porcelain Guanyin statue is popular among Christian believers in Japan as the icon of Mary, and its demand is so large that it is almost astonishing." [19] It can be seen that when ceramic decoration and modeling symbols enter a foreign culture, readers who accept them will perform different interpretations, bursting out the splendor of civilization and the colorfulness of culture. Chinese export porcelain crosses different cultures, adapts to different customs, explains different beliefs, and exudes a unique fragrance in the long history of the world.

\section{Conclusion}

Artifact civilization carries spiritual civilization. As a diplomat of foreign cultural exchanges, Chinese export porcelain records the progress of world history and civilization, and demonstrates the diversity of world religious culture. The sea loading method of exporting porcelain reflects the wisdom of the ancient Chinese, and its reasonable design not only saves transportation costs, but also increases the stability of maritime transportation and guarantees the safety of porcelain loading. The Christian culture and narrative stories on export porcelain not only bring romantic imagination to Chinese potters, but also add to the fanatical pursuit of Western worship of China. The export porcelain with Islamic culture not only recorded the prayers of believers at the time for the Islamic area from the decoration, but also recorded various plant decorations that were popular at that time. The huge porcelain shape satisfies the unique diet and daily needs of the Muslims in the Arab region, adapting to the way they grab the food with their fingers and drink boldly. The export porcelain that records Buddhist culture explains the meanings of concrete objects such as the lion and Guanyin statues in different cultures. The culture is colorful due to exchanges, and the civilization is splendid due to mutual learning. China's export porcelain plays an indispensable and important role in this period. The export porcelain embodying Taoist culture presents Chinese culture in front of the West. Chinese elements such as butterflies and pagodas become popular in Europe. Holy, auspicious and flawless spirit analyzed from the porcelains is enjoyed by people. Chinese ceramics, as artifacts, carry culture, demonstrate civilization, and witness the history of friendly exchanges between China and the West. Chinese export porcelain, replacing paper with porcelain, not only records the world's major civilizations, but also illuminates everyone who walks in the long history of the world. The light of Christ, the light of Islam and the light of Taoism on Chinese export porcelain bear culture, record civilization, and witness friendship.

\section{References}

[1] Robert Finlay. The Pilgrim Art: The culture of porcelain in world History. Journal of World History, Volume 9, 1998. p. 143.

[2] Xu Zhiheng. Yin Liu Zhai Shuo Ci. Ji Nan: Shan Dong pictorial Publishing, 2010, p 3.

[3] Sun Jinquan. The ways, methods and characters of Chinese porcelain exported to Europe. Journal of Sichuan University (Philosophy and Social Edition). 1997, p 26.

[4] Li Feng, Chinese Porcelain for the Spread of Religious Culture Ceramic Press, 2018. p 818-828.

[5] Cui Tong. An Analysis of the Pattern Features of Chinese Exported Porcelain in Qing Dynasty. 2013.

[6] Edited by Hua Derong, Chen Yaping, Zhong Yulong. Set sail all the way--the Yangzhou Grand Canal and Maritime Silk Road monographs. Nanjing: Southeast University Press, 2019.01 .

[7] Clare Le Corbeiller, China Trade Porcelain. Patterns of Exchange, New York: The Metropolitan Museum of Art, 1974, $\mathrm{p} 15$.

[8] Huang Jing, 2017. Jesus Porcelain in Export Porcelain in Ming and Qing Dynasty. Xi An: Collection.

[9] Cen Boming. The patterns of Tang and Song Yue Celadon Kiln at Shanglin Lake. Ningbo: Ningbo Publishing House, 2018.09. p 35.

[10] Chen Nianbin. The development of ceramics and auspicious patterns in the past dynasties. Journal of Jingdezhen Ceramics. 2003. vol. 13. p. 14.

[11] Jonathan M. Bloom, 1997. Sheila S. Blair. Islamic Arts (Phaidon Art \& Ideas). London: Phaidon Press.

[12] Edited by Ma Jiliang and Ma Jiwu. Chinese Ceramic Art. Tianjin: Tianjin Education Press, 2009.01.p 465.

[13] Edited by Wu Kang. Dictionary of Chinese Mysterious Culture. Haikou: Hainan Publishing House, 1993.04. p 71.

[14] Yu Xiangshun. Research on Chinese Lotus Aesthetic Culture. Chengdu: Bashu Publishing House, 2005.12. p 56.

[15] Kyousuke, 1941. Instructions for Research on Ancient Chinese Ceramics. Tokyo: Tokyo Osaka Rishu Store. 
[16] Huang Zhongjie. Art Studies about Collections of Chinese export Porcelains of Augustus II, King of Poland, Fujian Normal University, doctoral degree paper, 2012. p 65.

[17] Guo Lianfu and Mao Yanheng edited: "Summary of Chinese Design Theory" Nanjing: Jiangsu Phoenix Fine Arts Publishing House, 2017. p 505.

[18] Maxine Berg. Asian Luxuries and the Making of the European Consumer Revolution. In: Maxine Berg, Eger E. (eds) Luxury in the Eighteenth Century. Palgrave Macmillan, London. 2003. p 239 .
[19] Kyousuke: "Guide to Research on Ancient Chinese Ceramics", Tokyo: Tokyo-Osaka Ri Bookstore, 1941. p 326.

[20] Huang Jing, 2017. Cantonese Porcelain Sold to the Arab Region, India and Latin America. Xi An: Collection.

[21] Geng Baochang, Tu Hua, Ye Wencheng, etc.: "A Series of Famous Ancient Kilns in China-Dehua Kiln", Nanchang: Jiangxi Fine Arts Press, 2016. p 132. 